\title{
Influence of current and future climate on the seed germination of Cenostigma microphyllum (Mart. ex G. Don) E. Gagnon \& G. P. Lewis
}

\author{
Samara Elizabeth Vieira Gomes - Gilmara Moreira de Oliveira • \\ Marcelo do Nascimento Araujo • Charlotte E. Seal • Bárbara França Dantas
}

Received: 17 September 2018 / Revised: 31 May 2019/Accepted: 6 July 2019/Published online: 21 November 2019

(C) Institute of Botany, Czech Academy of Sciences 2019

\begin{abstract}
Seasonally tropical dry forests are among the most threatened environments by climate change. However, these forests, which are at risk of desertification, are still poorly studied and conserved. Seeds of several species endemic to the Caatinga, a Brazilian dry forest, are also understudied, mainly regarding their ability to cope with a hotter and drier climate predicted for the future. For the first time in seeds of Cenostigma microphyllum (Leguminosae), we aimed to study the presence of physical dormancy, temperature and salt tolerance to ascertain the effects of current and future climate on seed germination. Intact and scarified seeds were investigated by incubating at constant temperatures $\left(15\right.$ to $\left.40^{\circ} \mathrm{C}\right)$ or in $\mathrm{NaCl}$ solutions $(-0.2$ to $-1.0 \mathrm{MPa})$ at 25 and $30^{\circ} \mathrm{C}$. Thermal and osmotic thresholds, as well as thermal time and hydrotime constants, were calculated using linear
\end{abstract}

S. E. V. Gomes

Postgraduate Programme in Agronomy: Irrigated Horticulture, University of the State of Bahia, Avenida Edgard Chastinet Guimarães, São Geraldo, Juazeiro CEP: 48905-680 Bahia, Brazil

G. M. de Oliveira

Post-Programme on Plant Genetic Resources of the State University of Feira de Santana, Avenida Transnordestina, s/n Novo Horizonte, CEP 44036-900 Bahia, Brazil

\section{M. d. N. Araujo • B. F. Dantas $(\bowtie)$}

Uninassau College, Clementino Coelho, 714 - Centro, Petrolina PE, Pernambuco CEP 56308-210,, Brazil

e-mail: barbara.dantas@embrapa.br

C. E. Seal

Department of Comparative Plant and Fungal Biology, Royal Botanic Gardens, Kew, Wakehurst Place, Ardingly, UK regressions between the germination conditions and germination rate. To predict germination in the future, a heat sum model based on thermal time and hydrotime was applied to current and future climate scenarios. Seeds of C. microphyllum were permeable to water and did not have physical dormancy. The results indicated that increases in temperature are unlikely to affect germination, despite greater sensitivity to salinity presented at higher temperatures. In a future climate, the reduction in the number of weeks with at least $15 \mathrm{~mm}$ rainfall will affect the germination timing for the seeds. Thus, we can conclude that under the most pessimistic climate scenario predicted for the future, the seed germination of C. microphyllum may be restricted, likely leading to low seedling recruitment and establishment.

Keywords temperature - salt stress · climate change . thermal time model $\cdot$ hydrotime model

\section{Introduction}

The early stages of the plant life cycle, such as seed germination, seedling establishment and recruitment, are the most susceptible to environmental change for many species (Vieira and Scariot 2006). The mechanistic knowledge of ecological processes of seeds and seedlings of tropical forest species and their adjustment to stressful environments facilitates the use of restoration techniques with greater success (Pereira et al. 2013). In this sense, seeds of species which are adapted to local environmental conditions are more likely to 
tolerate temperature variation and extremes, lacking or excessive precipitation and changes in nutrient availability (Sovu et al. 2010).

Despite their distribution worldwide, most seasonally dry tropical forests occur as isolated patches and the only vast continuous area is the Caatinga Biogeographic Domain in north-eastern Brazil (Fernandes 2003). This ecosystem is characterized by vegetation adapted to a hot and semiarid climate with long periods of drought (Marengo 2014). Although the region shows good regeneration capacity of both its fauna and flora, increasing degradation of this ecosystem has resulted in intense desertification and, consequently, rapid loss of biodiversity (Marengo 2008; Siqueira Filho 2012). In addition, the Caatinga is predicted to be the most vulnerable Brazilian biome to a future climate scenario of global warming and decreased rainfall (Marengo 2014). According to the IPCC/AR5 projections for the semiarid northeastern region, the atmospheric temperature will increase by $1{ }^{\circ} \mathrm{C}$ until the middle of the century and will increase by $3.5^{\circ} \mathrm{C}$ by the end of the century. This indicates significantly hotter conditions and a decrease of almost 50\% in rainfall, thus worsening the water deficit in the region (IPCC 2014; Marengo 2014; PBMC 2014). This implies significant concerns for the Northeast region of Brazil regarding the socio-environmental effects of climate change and how these changes influence desertification process and the extinction of endemic species.

In arid and semiarid regions, the low rainfall, high temperature and evaporation contribute decisively to a greater water deficit and greater salinization of the soils (Pedrotti et al. 2015). In the Caatinga, saline soils are formed by the chemical weathering of rocks and by the rise of brackish groundwater due to high evaporation (Hirata et al. 2006). For Caatinga species, water is a particularly important factor because it is available in the soil in sufficient quantity for germination and seedling recruitment during only 3 to 4 months of the year, between December and March (Moura et al. 2007).

With more than 1,500 plant species occupying the Caatinga (Queiroz 2009), the diaspores of only 352 have been studied, with the Leguminosae family being the most widely reported (88 species from 49 genera; Meiado et al. 2012). There is no information on the seed germination traits of Cenostigma microphyllum (Mart. ex G. Don) E. Gagnon \& G. P. Lewis, despite its restricted distribution in Northeastern Brazil and its ecological and economic value. Furthermore, few studies have related germination to current climatic data and future climate scenarios to predict if the germination of native Caatinga species will be limited in the future (Oliveira et al. 2019). Thus, in this study, we aimed to address the following questions for C. microphyllum: (1) Do seeds exhibit seed coat physical dormancy? (2) What are the temperature limits to seed germination?

(3) What are the effects of salinity on germination?

(4) Considering future climate predictions of temperature increase and decrease in precipitation, how will germination be affected by such changes?

\section{Material and methods}

\section{Study species}

Cenostigma microphyllum is a Leguminosae shrub endemic to the Caatinga. It is distributed in a relatively small area including the areas south of Piauí, south of Pernambuco and north of Bahia. This species has both economic and ecological importance. The wood is widely used in construction and as fuel, whereas the bark and flowers are used in traditional medicine for stomach ailments (Queiroz 2009). It is a nurse species, which favors the germination and the establishment of seedlings that grow under its canopy, thus creating positive interplant interactions (Paterno et al. 2016).

\section{Collection, processing and storage of seeds}

Mature fruits of C. microphyllum were collected from 50 shrubs in Petrolina, Pernambuco State, northeastern Brazil (09¹9'50.8' S, 040³2'55.4" W, 374 a.s.1.). The fruits were manually collected before dehiscence, when their colour was changing from green to brown. After harvest, the fruits were dried on a canvas and protected from rain and sun until the fruit dehisced and the seeds were manually separated from the fruit remains (Matias et al. 2014). Although there is no information about the effect of seed storage on this species, seeds of C. pyramidale stored at similar conditions for more than six months showed no change in germination percentage and speed (Antunes et al. 2010). Thus, after processing seeds were placed in labelled plastic bags and stored in a temperature- and humidity-controlled room $\left(10 \pm 2^{\circ} \mathrm{C}\right.$ and $\left.40 \pm 5 \% \mathrm{RH}\right)$ for no more than 2 months until the beginning of the experiments. 
Scarification and germination at constant temperatures

Intact and scarified seeds were used to evaluate the presence of physical dormancy. Seeds were scarified by cutting the seed coat with steel scissors $(9 \times 5 \times 2 \mathrm{~cm})$ in the region opposite the hilum.

The treatments were randomized in a $6 \times 2$ factorial arrangement (six temperatures: 15, 20, 25, 30, 35 and $40^{\circ} \mathrm{C}$; using intact and scarified seeds). For each treatment, 100 seeds were used; these seeds were divided into four replicates of 25 each. The seeds were divided into acrylic boxes $(11 \times 11 \times 3.5 \mathrm{~cm})$, which had been previously sterilized with concentrated sodium hypochlorite for $15 \mathrm{~min}$. Each box contained two sheets of filter paper $(10.5 \times 10.5 \mathrm{~cm})$ moistened with distilled water, equivalent in volume to 2.5 times the weight of the dry substrate (Brazil 2009). Seeds were incubated in Biochemical Oxygen Demand (BOD)-type germinators over a period of 22 days, adjusted to maintain constant temperatures of 15 to $40^{\circ} \mathrm{C}$, at increments of $5^{\circ} \mathrm{C}$ with a 12-h photoperiod.

Germination at different temperatures and osmotic potentials

Based on the results for scarification, intact seeds were used to evaluate the influence of temperature on the germination of $C$. microphyllum seeds at different osmotic potentials. The treatments were randomized in a 6 $\times 2$ factorial arrangement, represented by six osmotic potentials $(0.0,-0.2,-0.4,-0.6,-0.8$ and $-1.0 \mathrm{MPa})$ at two temperatures $\left(25\right.$ and $\left.30^{\circ} \mathrm{C}\right)$. The osmotic solutions were prepared according to the van't Hoff equation (Lang 1967), with solutions of sodium chloride $(\mathrm{NaCl})$ in distilled water. For each treatment, 100 seeds divided into four replicates of 25 seeds were used, which were, as previously described, sown in acrylic boxes, on filter paper moistened with $10 \mathrm{~mL}$ of $\mathrm{NaCl}$ solutions in distilled water. Boxes were sealed with Parafilm ${ }^{\circledR}$ and incubated in BOD-type germinators adjusted for constant temperatures at 25 or $30^{\circ} \mathrm{C}$ and a 12 -h photoperiod. Every three days, $10 \mathrm{~mL}$ of solution was added to the substrate to maintain a constant osmotic potential.

\section{Germination evaluation}

Over a period of 22 days, daily counts were performed and seeds with protrusion of the primary root longer than $2.0 \mathrm{~mm}$ were considered to have germinated. Based on the daily germination data, the germination percentage, germination speed index (GSI; Maguire 1962) and germination uniformity coefficient (GUC, Ranal and Santana 2006) were estimated. The data were checked for normality and homoscedasticity by Shapiro-Wilk and Levene tests, respectively. If data were normal and homoscedastic, these were interpreted using an analysis of variance (ANOVA) and the means were compared using the Tukey test at a significance level of $5 \%$ by the program Assistat (Silva and Azevedo 2016). Data that did not follow a normal distribution were arcsinetransformed and re-tested. If the data were still considered non-normal, analysis was conducted by the non-parametric Kruskal-Wallis test at a significance level of $5 \%$.

Modelling of germination data

\section{Thermal time}

Germination percentage at each temperature was plotted against time, creating cumulative germination curves, which were then fitted using a Boltzman function (Oliveira et al. 2019). From these curves, the germination rate (GR, reciprocal of the time required for $50 \%$ germination, $\mathrm{GR}=1 / t_{50}$ ) was calculated separately for sub- and supra-optimal temperatures (Covell et al. 1986). A linear regression analysis was performed to calculate the $\mathrm{x}$-axis intercept of both the sub- and supraoptimal temperatures, which provided estimates of the base $\left(T_{\mathrm{b}}\right)$ and ceiling temperatures $\left(T_{\mathrm{c}}\right)$ for germination. Below and above $T_{\mathrm{b}}$ and $T_{\mathrm{c}}$, respectively, the GR equals zero (Covell et al. 1986; Ellis et al. 1986). The intersection of the linear sub- and supra-optimal temperature regression lines was used to estimate the optimal temperature $\left(\mathrm{T}_{\mathrm{o}}\right.$; Hardegree 2006).

The thermal time of the population that germinated at sub-optimal temperatures $\left(\theta_{\text {Tsub }}\right)$ and supra-optimal temperatures $\left(\theta_{\text {Tsupra }}\right)$ was the reciprocal of the slope of each linear regression, respectively (Covell et al. 1986).

\section{Hydrotime}

Germination percentage at each osmotic potential $(\Psi)$ were plotted against time and fitted using a Boltzman function (Oliveira et al. 2019), from which $1 / t_{50}$ was calculated. At each temperature, a linear regression analysis was performed between $1 / t_{50}$ and $\Psi$, and the 
intercept on the $\mathrm{x}$-axis was calculated to provide an estimate of the base osmotic potential $\left(\Psi_{\mathrm{b}}\right)$ below which GR is equal to zero (Gummerson 1986). Seed germination responses to the osmotic potential were also described using a hydrotime scale $\left(\theta_{\mathrm{H}}\right)$ calculated for each treatment level of salinity by the reciprocal of the slope (Gummerson 1986; Bradford 1995).

Prediction of germination under current and future climatic scenarios

To predict seed germination under different climate scenarios, historical climatic data were obtained from the Agrometeorology Laboratory of Embrapa Semiarid, specifically the meteorological station of the Caatinga Experimental Field $\left(09^{\circ} 13^{\prime} \mathrm{S}, 40^{\circ} 29^{\prime} \mathrm{W}\right)$ to represent the current climate. Future climate scenarios were taken from the Fifth Report of the Intergovernmental Panel on Climate Change (IPCC/AR5), namely RCP $2.6\left(+1^{\circ} \mathrm{C}\right)$ and RCP $8.5\left(+3.5^{\circ} \mathrm{C}\right.$; IPCC 2014), with reductions of precipitation of $25 \%$ and $40 \%$, respectively predicted by the Brazilian Panel on Climate Change (PBMC 2014). Because each $1{ }^{\circ} \mathrm{C}$ increase in air temperature is associated with a $1.5^{\circ} \mathrm{C}$ increase in soil temperature (Ooi et al. 2012), we estimated soil temperature under current and future climate scenarios.

An environmental heat sum (the thermal requirement for germination to occur) was calculated using soil temperature. The heat sum was calculated weekly according to the following equation:

$$
\text { Heat sum }=\left(\mathrm{T}_{\mathrm{m}}-\mathrm{T}_{\mathrm{b}}\right) / \mathrm{t}\left[{ }^{\circ} \mathrm{C} \cdot \mathrm{d}^{-1}\right]
$$

where $T_{\mathrm{m}}$ is the weekly mean soil temperature, $T_{b}$ is the base temperature below which there is no germination and $t$ is the number of days needed to reach the thermal time for germination $\left(\theta_{\mathrm{T}}\right)$. Small rainfall events ( 5 to 10 $\mathrm{mm}$ ) in semi-arid environments are effective to increase soil microbial activity (Schimel et al. 1999) and trigger rapid physiological responses in well adapted dryland plants (Sala and Lauenroth 1982). Thus, we only considered the heat sum effective when the weekly precipitation was at least $15 \mathrm{~mm}$ (equivalent to three $5 \mathrm{~mm}$ rainfall events).

\section{Results}

Influence of scarification on germination

Scarification resulted in a significantly lower final germination percentage $(73 \%)$ than observed for intact seeds (77\%; $P<0.05, F=4.245)$. There was no interaction between scarification and temperature $(P=0.782$, $F=0.489$ ).

On the other hand, the interaction of scarification and temperature had a significant effect on germination speed and uniformity $(P<0.05)$. However, scarification had a significant effect on GSI only at 15 and $40^{\circ} \mathrm{C} \mathrm{C}$. At $20^{\circ} \mathrm{C}$, GSI of scarified seeds was higher than that of the intact seeds, indicating that germination was faster. As there were few benefits to germination using the scarification treatment, it was decided to use intact seeds for the remaining experiments.

\section{Influence of temperature on germination}

Over $85 \%$ germination was achieved at temperatures between 15 and $35^{\circ} \mathrm{C}$ (Table 1). At $40^{\circ} \mathrm{C}$, only $15 \%$ germinated. At temperatures of 20 to $40^{\circ} \mathrm{C}$ the germination was more uniform (higher GUC; Table 1). The GSI, which considers the percentage and speed of germination, was higher in seeds that germinated at 20 and $35^{\circ} \mathrm{C}$ than at 15 or $40^{\circ} \mathrm{C}$ (Table 1 ).

The thermal limits for the germination of C. microphyllum seeds were obtained using linear regressions relating temperature and $1 / t_{50}\left(R^{2}\right.$ : sub-optimal temperature $=0.7852$ and supra-optimal temperature $=$ 0.6265 ; Fig. 1a). The optimum temperature $\left(T_{\mathrm{o}}\right)$ was estimated to be $25.9^{\circ} \mathrm{C}$, the base temperature $\left(T_{\mathrm{b}}\right)$ was $11.6^{\circ} \mathrm{C}$ and the ceiling temperature $\left(T_{\mathrm{c}}\right)$ was $55.4^{\circ} \mathrm{C}$ (Fig. 1a). $\theta_{\text {Tsub }}$ and $\theta_{\text {Tsupra }}$ were estimated as 729 and $1.448^{\circ} \mathrm{C} \cdot \mathrm{d}^{-1}$, respectively.

Influence of temperature on germination in salt solutions

At 25 and $30^{\circ} \mathrm{C}$, germination decreased with the gradual increase in the concentration of $\mathrm{NaCl}$ (Table 2). Germination was highest at $25^{\circ} \mathrm{C}$ from -0.2 to $-0.6 \mathrm{MPa}$ and was significantly reduced at lower osmotic potentials. At $30^{\circ} \mathrm{C}$, no germination occurred below $-0.6 \mathrm{MPa}$. This result contrasted with that at $25^{\circ} \mathrm{C}$, where germination was lower but continued until-1.0 MPa. 
Table 1 Germination percentage (\%), germination uniformity coefficient (GUC) and germination speed index (GSI) of Cenostigma microphyllum. Seeds were either scarified or intact and germinated at constant temperatures from 15 to $40^{\circ} \mathrm{C}$.

\begin{tabular}{|c|c|c|}
\hline Scarification & Germination $[\%]$ & GUC $\left[\right.$ day $\left.^{-2}\right]$ \\
\hline Intact seeds & $77.33 \mathrm{a}$ & $0.4613 \mathrm{a}$ \\
\hline Scarified seeds & $73.66 \mathrm{~b}$ & $0.8751 \mathrm{a}$ \\
\hline \multicolumn{3}{|l|}{ Temperature $\left[{ }^{\circ} \mathrm{C}\right]$} \\
\hline 15 & $85.0 \mathrm{a}$ & $0.067 \mathrm{~b}$ \\
\hline 20 & $85.5 \mathrm{a}$ & $1.044 \mathrm{a}$ \\
\hline 25 & $86.0 \mathrm{a}$ & $0.599 \mathrm{a}$ \\
\hline 30 & $85.0 \mathrm{a}$ & $0.498 \mathrm{ab}$ \\
\hline 35 & $93.5 \mathrm{a}$ & $0.547 \mathrm{ab}$ \\
\hline \multirow[t]{4}{*}{40} & $15.0 \mathrm{~b}$ & $1.255 \mathrm{a}$ \\
\hline & $C V[\%]=8.16 ; W=0.250^{\mathrm{ns}} ; F=2.016^{\mathrm{ns}}$ & $C V[\%]=79.27 ; W=0.000 * ; F=5.416 * *$ \\
\hline & GSI [germinated seeds $\cdot$ day $\left.^{-1}\right]$ & \\
\hline & Scarification & \\
\hline Temperature $\left[{ }^{\circ} \mathrm{C}\right]$ & Intact seeds & Scarified \\
\hline 15 & $2.1196 \mathrm{cA}$ & $2.2508 \mathrm{bA}$ \\
\hline 20 & $5.3369 \mathrm{bB}$ & $6.3292 \mathrm{aA}$ \\
\hline 25 & $6.0518 \mathrm{aA}$ & $5.9786 \mathrm{aA}$ \\
\hline 30 & $6.2723 \mathrm{aA}$ & $5.7738 \mathrm{aA}$ \\
\hline 35 & $6.4250 \mathrm{aA}$ & $6.3661 \mathrm{aA}$ \\
\hline \multirow[t]{2}{*}{40} & $1.1250 \mathrm{dA}$ & $0.9083 \mathrm{cA}$ \\
\hline & $C V[\%]=8.85 ; W=0.230^{\mathrm{ns}} ; F=1.428^{\mathrm{ns}}$ & \\
\hline
\end{tabular}

Germination and GSI mean values followed by the same letter, lowercase in the columns and uppercase in the rows, do not differ from each other based on ANOVA with a post-hoc Tukey test at 5\% significance level. GUC mean values followed by the same letter, lowercase in the columns, do not differ from each other based on the Kruskal-Wallis ranking values at $5 \%$ probability.

$C V$ - coefficient of variation; $W$ - Shapiro-Wilk's test statistics for data normality; $F$ - Levene's test statistics for homoscedasticity; ${ }^{\text {ns }}-$ not significant; $* *-P<0.01$

At $30^{\circ} \mathrm{C}$, the GSI was affected by the increase of $\mathrm{NaCl}$ concentration, with a significant reduction beyond $-0.8 \mathrm{MPa}$ (Table 2). However, at $25^{\circ} \mathrm{C}$, the GSI did not significantly differ from -0.4 to $-1.0 \mathrm{MPa}$. No differences were observed in the GUC values at $25^{\circ} \mathrm{C}$ at any osmotic potential. At $30^{\circ} \mathrm{C}$, germination was more uniform from -0.2 to $-0.6 \mathrm{MPa}$.

Using values of $1 / t_{50}$, an evaluation of the effect of temperature on germination under different osmotic potentials from saline solutions indicated the $\Psi_{\mathrm{b}}$ was $-1.8 \mathrm{MPa}\left(\sim 50 \mathrm{dS} \cdot \mathrm{m}^{-1}\right)$ at $25^{\circ} \mathrm{C}$ and around $-1.1 \mathrm{MPa}\left(\sim 30 \mathrm{dS} \cdot \mathrm{m}^{-1}\right)$ at $30^{\circ} \mathrm{C}$ (Fig. 1b).

Germination of the C. microphyllum seeds under current and future climate change scenarios

Based on the results obtained from the thermal and hydro time models, the environmental heat sum for germination to occur was calculated only when there was a rainfall volume over $15 \mathrm{~mm}$ (Fig. 2). The modelling of germination of the current climate and the future scenarios (RCP 2.6 and 8.5) shows that the predicted temperature increase will not limit the germination of C. microphyllum, as the soil temperature will always be lower than the $T_{\mathrm{c}}$ of the seeds. With a reduction in the precipitation index of $25 \%$ in the RCP 2.6 scenario (Fig. 2b) and of more than $40 \%$ in the RCP 8.5 scenario (Fig. 2c), the number of weeks that germination may occur is reduced from 14 to 6 weeks.

\section{Discussion}

Several Caatinga seeds, mainly of the Leguminosae family, commonly have integuments that are impermeable to water (Freire et al. 2017) and are thus can be classified with physical dormancy (Baskin and Baskin 2004). Physical dormancy is often identified in seeds 


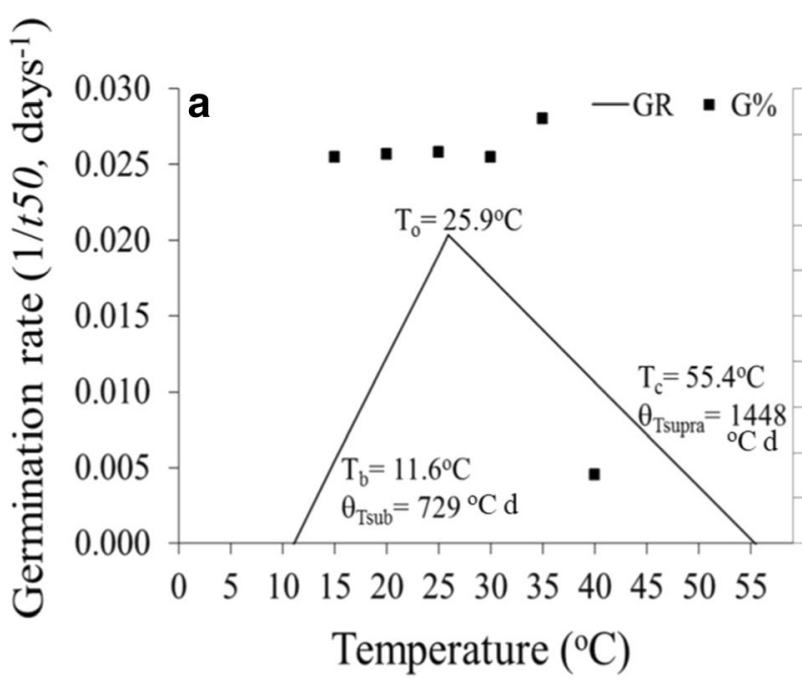

Fig. 1 Germination rate (GR) and percentage $(G \%)$ of intact seeds of $C$. microphyllum incubated at different temperatures A - in distilled water $\left(R^{2}:\right.$ GR at sub-optimal temperatures = $0.785^{* *}$ and GR at supra-optimal temperatures $=0.627 *$ ) and B - in different osmotic potentials at 25 (GR25 and G\%25) and $30^{\circ} \mathrm{C}\left(\mathrm{GR} 30\right.$ and $G \% 30 ; R^{2}: \mathrm{GR} 25=0.667^{*}$ and GR30 $\left.=0.627^{*}\right)$.

produced in dry environments (Cardoso 2004). However, when the seed collection sites are compared for some Leguminosae such as Cenostigma pyramidale (Tul.) Gagnon \& G.P. Lewis, which are found throughout the Caatinga, there is evidence that species behave differently according to their maternal location (Alves et al. 2007; Dantas et al. 2008; Antunes et al. 2010). Seeds of C. pyramidale, harvested at sites close to those used in this study, do not exhibit physical dormancy either (Antunes et al. 2010; Dantas et al. 2008; Dantas et al. 2014). However, at less favorable germination temperatures $\left(15\right.$ and $\left.40^{\circ} \mathrm{C}\right)$, scarification allowed greater speed and more uniformity of germination. Thus, even though no deep physical dormancy exists, scarification is linked to a wider thermal envelope for germination. This is advantageous for seeds in semiarid environments such as the Caatinga, where germinate is required to complete as quickly as possible during the short time when water is available. C. microphyllum is an important forage species in the Caatinga (Wiersema and León 2016), and the scarification of the seed coat can occur by acid and mechanical digestion during rumination of sheep and goats. Also, the seed coat can weaken by the action of the microorganisms present in the soil (VásquezYanes and Orozco-Segovia 1993) or due to specific changes in the environment, such as thermal fluctuations (Fenner and Thompson 2005).

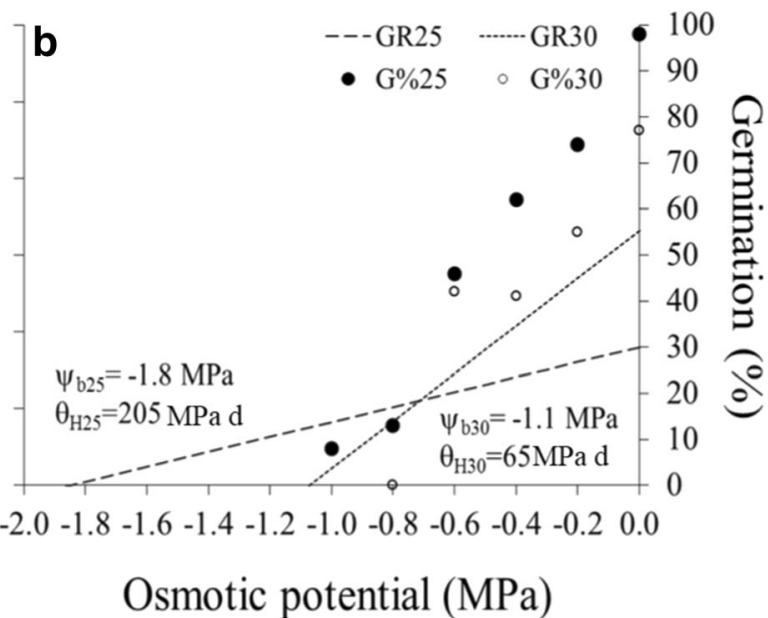

$T_{\mathrm{o}}$-optimal temperature for germination; $T_{\mathrm{b}}$ - base temperature; $T_{\mathrm{c}}$ - ceiling temperature; $\Phi_{\text {Tsub }}$ - thermal time at suboptimal temperatures; $\Phi_{\text {Tsupra }}$ - thermal time at supraoptimal temperatures; $\Psi_{\mathrm{b} 25}$ and $\Psi_{\mathrm{b} 30}$ - base osmotic potential at 25 and $30^{\circ} \mathrm{C}$, respectively; and $\Phi_{\mathrm{H} 25}$ and $\Phi_{\mathrm{H} 30}-$ hydrotime at 25 and $30^{\circ} \mathrm{C}$, respectively. ${ }^{*}-P<0.05 ; * *-P<0.01$.

Seeds of Caatinga species usually germinate over a wide temperature range to cope with temperature fluctuations of the region (Oliveira et al. 2019). The GR threshold model estimated a $T_{\mathrm{c}}$ of $55.4^{\circ} \mathrm{C}$ although the germination experiment did not test these conditions (Fig. 1). Native seeds of the Caatinga are known to be tolerant to high temperatures and a small percentage can germinate at temperatures as high as $40^{\circ} \mathrm{C}$, such as seen for Myracrodruon urundeuva (Oliveira et al. 2019), at $45^{\circ} \mathrm{C}$, such as Discocactus zehntneri subsp. petr-halfarii (Nascimento et al. 2018), and at $47^{\circ} \mathrm{C}$, such as Anadenanthera colubrina var. cebil (unpublished data).

This ability to germinate over a wide range of temperatures, from a $T_{\mathrm{b}}$ of $11.6^{\circ} \mathrm{C}$ to a $T_{\mathrm{c}}$ of $55.4^{\circ} \mathrm{C}$ (Fig. 1), demonstrates that if water is available, $C$. microphyllum seeds can potentially germinate at any time of the year in the Caatinga region. In this region, historical data has shown that minimum air temperature is never below $12^{\circ} \mathrm{C}$ (Moura et al. 2007) and warming due to climate change could result in soil temperatures of up to $47^{\circ} \mathrm{C}$ (IPCC 2014; Marengo 2014). Similar results were found for different species adapted to this environment, such as Myracrodruon urundeuva (Oliveira et al. 2019), Amburana cearensis (Guedes et al. 2010) and Anadenanthera colubrina (Paim et al. 2016), which showed high germination within an average air temperature range of 15 to $35^{\circ} \mathrm{C}$. The data obtained for 
Table 2 Temperature and germination (\%), index of germination velocity (GSI), and germination uniformity coefficient (GUC) of C. microphyllum seeds imbibed in $\mathrm{NaCl}$ at different osmotic potentials $(0.0,-0.2,-0.4,-0.6,-0.8$ and $-1.0 \mathrm{MPa})$ at 25 and $30^{\circ} \mathrm{C}$

\begin{tabular}{|c|c|c|c|}
\hline & Germination [G\%] & GSI [seeds·day ${ }^{-1}$ ] & GUC $\left[\right.$ day $\left.^{-2}\right]$ \\
\hline Temperature & $25^{\circ} \mathrm{C}$ & & \\
\hline \multicolumn{4}{|l|}{ Osmotic potentials } \\
\hline 0 & $98.0 \mathrm{a}$ & $4.252 \mathrm{a}$ & $0.144 \mathrm{a}$ \\
\hline-0.2 & $74.0 \mathrm{ab}$ & $3.251 \mathrm{ab}$ & $0.130 \mathrm{a}$ \\
\hline-0.4 & $62.0 \mathrm{abc}$ & $2.873 \mathrm{abc}$ & $0.068 \mathrm{a}$ \\
\hline-0.6 & $46.0 \mathrm{abc}$ & $1.222 \mathrm{abc}$ & $0.150 \mathrm{a}$ \\
\hline-0.8 & $13.0 \mathrm{bc}$ & $0.289 \mathrm{bc}$ & $0.616 \mathrm{a}$ \\
\hline-1.0 & $8.0 \mathrm{bc}$ & $0.207 \mathrm{bc}$ & $2.125 \mathrm{a}$ \\
\hline$P$ value $(\alpha=0.05)$ & 0.000 & 0.001 & 0.387 \\
\hline Temperature & $30^{\circ} \mathrm{C}$ & & \\
\hline \multicolumn{4}{|l|}{ Osmotic potentials } \\
\hline 0 & $77.0 \mathrm{a}$ & $4.200 \mathrm{a}$ & $0.558 \mathrm{ab}$ \\
\hline-0.2 & $55.0 \mathrm{ab}$ & $2.149 \mathrm{ab}$ & $1.048 \mathrm{ab}$ \\
\hline-0.4 & $41.0 \mathrm{ab}$ & $1.729 \mathrm{ab}$ & $0.636 \mathrm{ab}$ \\
\hline-0.6 & $42.0 \mathrm{ab}$ & $1.992 \mathrm{ab}$ & $2.063 \mathrm{a}$ \\
\hline-0.8 & $0 \mathrm{~b}$ & $0 \mathrm{~b}$ & $0 \mathrm{~b}$ \\
\hline-1.0 & $0 \mathrm{~b}$ & $0 \mathrm{~b}$ & $0 \mathrm{~b}$ \\
\hline \multirow[t]{3}{*}{$P$ value $(\alpha=0.05)$} & 0.001 & 0.001 & 0.002 \\
\hline & $C V \%=13.45$ & $C V \%=15.32$ & $C V \%=143.99$ \\
\hline & $W=0.007^{*} ; F=3.465^{*}$ & $W=0.042^{*} ; F=2.318^{*}$ & $W=0.000^{*} ; F=17.701^{*}$ \\
\hline
\end{tabular}

Mean values followed by the same letter, lowercase in the columns, do not differ from each other based on the Kruskal-Wallis ranking values at $5 \%$ probability

$C V$ - coefficient of variation; $W$ - Shapiro-Wilk's test statistics for data normality; $F$ - Levene's test statistics for homoscedasticity; ${ }^{\text {ns }}-$ not significant; $*-P<0.05$

C. microphyllum showed that a high percentage of germination occurred at $15^{\circ} \mathrm{C}$, but the time taken for germination was three times slower at $15^{\circ} \mathrm{C}$ than at $25^{\circ} \mathrm{C}$ (Table 1; Fig. 1). This may be undesirable, since agility during germination is very important to reduce seed and seedling exposure to unfavorable environmental conditions (Alves et al. 2014). However, an air temperature of $15^{\circ} \mathrm{C}$ is seldom encountered at Caatinga regions where C. microphyllum occurs.

Saline solutions retain water that would otherwise be available for germination, thus reducing the water potential of the substrate, resulting in lower water availability for the seed (Nasr et al. 2012). This lack of accessibility to water also prolongs the time required for the absorption of water by the seeds (Moreno et al. 2018). Consistent with this, at $30^{\circ} \mathrm{C}$, the germination of C. microphyllum at osmotic potentials lower than $-0.6 \mathrm{MPa}$ was reduced and where germination did occur, it was slower. This suggests that the combination of faster influx of saline solution associated with the higher temperature and toxicity caused by excess $\mathrm{Na}^{+}$(Alsaeedi et al. 2018) has a detrimental effect on germination, in comparison to $25^{\circ} \mathrm{C}$.

As well as experiencing limited water, Caatinga soils are also affected by salinity. Furthermore, in this region of Northeast Brazilian, $30 \%$ of its area is geologically formed by peculiar crystalline rocks, which upon weathering produce brackish groundwater with an electrical conductivity of around $4 \mathrm{dS} \cdot \mathrm{m}^{-1}$ (SUDENE 1980). Unfortunately, as the forecast for the IPCC/AR5 report is a reduction of up to $50 \%$ in the amount of rainfall in the Northeast over the next 80 years, it can be anticipated that salinity will increase in these soils (IPCC 2014). Thus, although seeds are tolerant to osmotic potentials of $\mathrm{NaCl}$ lower than $-1 \mathrm{MPa}\left(>15 \mathrm{dS} \cdot \mathrm{m}^{-1}\right)$, the lack of rainfall may still restrict seed germination. 

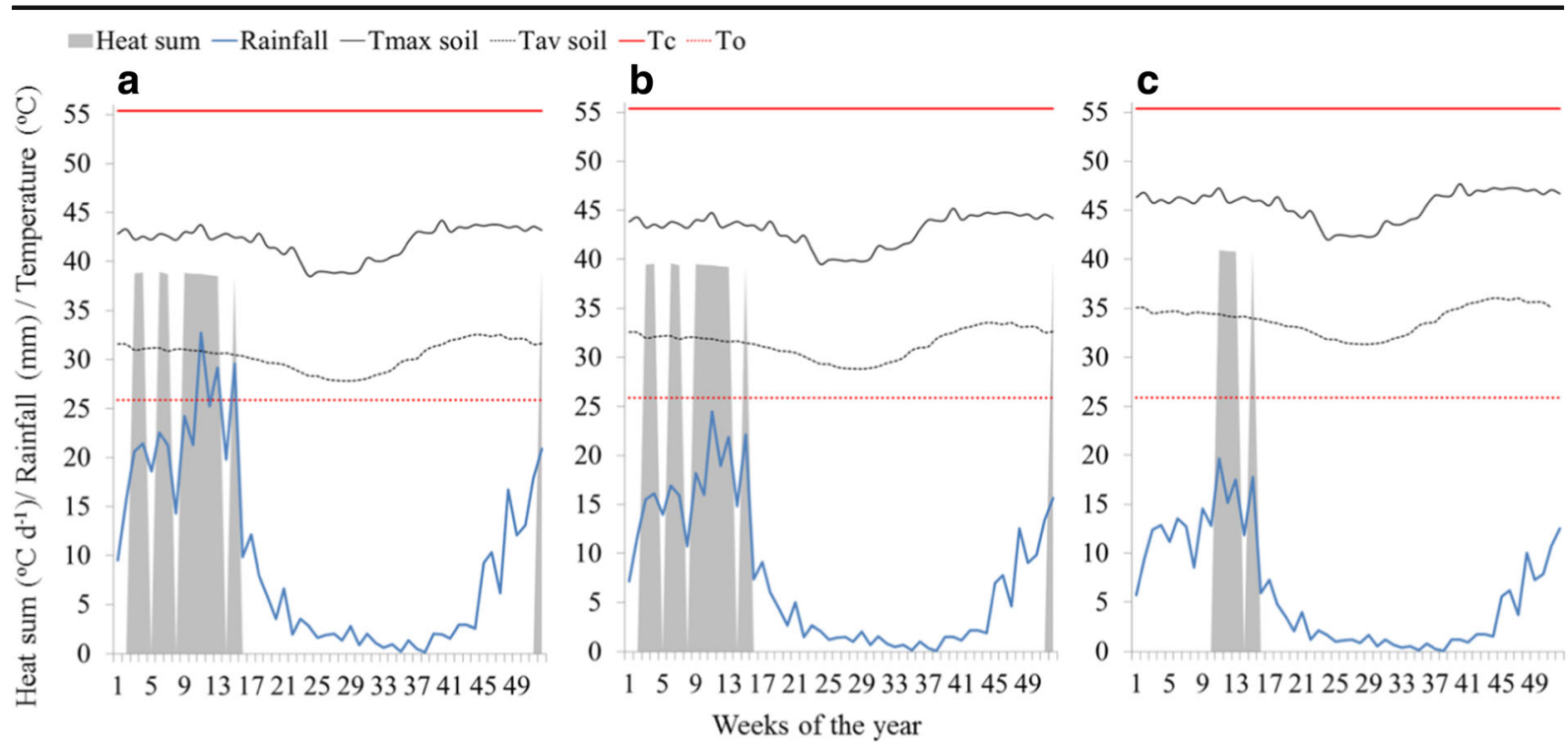

Fig. 2 Environmental heat sum needed for germination events of C. microphyllum under current climatic scenarios (A) and projected climate change scenarios RCP 2.6 (B) and RCP 8.5 (C) from the Fifth Report of the Intergovernmental Panel on Climate Change - IPCC/AR5 (IPCC 2014). Heat sum - calculated

Species occurring in dry tropical forests, such as the Caatinga, must have strategies to overcome factors such as low water availability, salinity and high temperatures in order to allow fast seedling emergence and for plants to establish (Merino-Martín et al. 2017). In this sense, the results of this work indicate that in order to cope with the most pessimistic climate change scenario, studies are needed on how to promote reforestation by increasing the number of seeds that germinate and seedlings that establish quickly taking advantage of the short time of available water. In this way, species with highly tolerant seeds may be more efficient for use in environmental restoration.

The most pessimistic scenario of an increase of $3.5^{\circ} \mathrm{C}$ in air temperature $\left(+5.25^{\circ} \mathrm{C}\right.$ soil temperature $)$ and a $40 \%$ reduction in precipitation index, predicts a decrease in the number of weeks of rainfall suitable for germination to occur (Fig. 2c). The rainfall of at least 15 to $20 \mathrm{~mm}$ per week is considered the volume of rain needed to maintain soil moisture that provides seed germination for a week (Santos et al. 2011). Thus, by the end of the century, the time period of water availability useful for germination, as well as seedling development and establishment, is estimated to be reduced for $C$. microphyllum (Fig. 2c)and for Myracrodruon urundeuva Allemão (Oliveira et al. 2019).. As such, seeds that are able to germinate might not produce heat sum $\left({ }^{\circ} \mathrm{C} \cdot \mathrm{d}^{-1}\right)$ for germination events when rainfall was $>15$ $\mathrm{mm}$; Rainfall - accumulated weekly rainfall; $T_{\max }$ soil - maximum soil temperature; $T_{\text {av soil }}$ - average soil temperature; $T_{\mathrm{c}}-$ ceiling temperature for seed germination. $\mathrm{T}_{\mathrm{o}}$ - optimum temperature for seed germination.

seedlings tolerant to dry conditions during the dry season and thus seedling establishment may fail.

For the first time, we report that seeds of C. microphyllum do not have physical dormancy. Climatic temperature increases will not influence the germination of the species because this will not exceed $T_{\mathrm{c}}$ for germination to occur. However, the anticipated decrease in precipitation will lead to a shorter time period for the recruitment of seedlings that are able to tolerate the dry season until the next rainy season. Although seeds are tolerant to electric conductivities higher than found in Caatinga soils currently, the increase of soil temperature and water deficit will lead to increased salinity through capillarity of brackish groundwater, which might restrict seed germination in some sites of the Caatinga biome.

\section{References}

Al-Ahmadi MJ, Kafi M (2007) Cardinal temperatures for germination of Kochia scoparia (L.). J Arid Environm 68:308-314

Alsaeedi A, El-Ramady H, Alshaal T, El-Garawani M, Elhawat N, Al-Otaibi A (2018) Exogenous nanosilica improves germination and growth of cucumber by maintaining $\mathrm{K}+\mathrm{Na}+$ ratio under elevated Na+ stress. Pl Physiol Biochem 125:164-171

Alves EU, Cardoso EDA, Bruno RDLA, Alves AU, Galindo EA, Braga Junior JM (2007) Superação da dormência em 
sementes de Caesalpinia pyramidalis Tul. Rev Árv 31:405415

Alves MM, Alves EU, Santos Silva-Moura S, Araújo LR, Santos Silva R, Ursulino M M (2014) Emergência e crescimento inicial de plântulas de Platymiscium $\ddot{\imath}\urcorner$, orinbundum Vog. em função de diferentes posições e profundidades de semeadura. Cienc. Rural 44:2129-2135

Antunes CGC, Pelacani CR, Ribeiro RC, Gomes HLR, Castra RD (2010) Influência do armazenamento na qualidade fisiológica de sementes de Caesalpinia pyramidalis Tul. Rev Árv 34: $1001-1008$

Baskin JM, Baskin CC (2004) A classification system for seed dormancy. Seed Sci Res 14:1-16

Bradford KJ (1995) Water relations in seed germination. Seed Developm Germination 1:351-396

Cardoso VJ (2004) Dormência: estabelecimento do processo. Germinação: do básico ao aplicado. Porto Alegre, Artmed, pp 95-108

Covell S, Ellis RH, Roberts EH, Summerfield RJ (1986) The influence of temperature on seed germination rate in grain legumes. J Exp Bot 37:705-715

Dantas BF, Correia JS, Marinho LB, Aragão CA (2008) Alterações bioquímicas durante a embebição de sementes de catingueira (Caesalpinia pyramidalis Tul.). Revista Brasil Sementes 30:221-227

Dantas BF, Ribeiro RC, Matias JR, Araujo GGL (2014) Germinative metabolism of Caatinga forest species in biosaline agriculture. J Seed Sci, 36: 194-203

Ellis RH, Covell S, Roberts EH, Summerfield RJ (1986) The influence of temperature on seed germination rate in grain legumes. II. Interspecific variation in chickpea (Cicer arietinum L.) at temperature. $J$ Exp Bot 37:1503-1515

Fenner M, Thompson K (2005) The ecology of seeds. Cambridge University Press

Fernandes A (2003) Conexões florísticas do Brasil. Banco do Nordeste, Fortaleza

Freire JM, Sousa TJES, Ataide GM, Breier TB, Rouws JIRC (2017) Influence of pre-germination treatments on germination seed in Melanoxylon brauna Schott. African J Agric Res 12:3149-3153

Grossiord C, Sevanto S, Dawson TE, Adams HD, Collins AD, Dickman LT, McDowell NG (2017) Warming combined with more extreme precipitation regimes modifies the water sources used by trees. New Phytol 213:584-596

Guedes RS, Alves EU, Gonçalves EP, Braga Júnior JM, Viana JS, Colares PNQ (2010) Substratos e temperaturas para testes de germinação e vigor de sementes de Amburana cearensis (Allemão) AC Smith. Rev Árv 34:57-64

Gummerson RJ (1986) The effect of constant temperatures and osmotic potentials on the germination of sugar beet. $J$ Exp Bot 37:729-741

Hardegree SP (2006) Predicting germination response to temperature. I. Cardinal-temperature models and subpopulationspecific regression. Ann Bot (Oxford) 97:1115-1125

Hirata R, Zobbi J, Fernandes A, Bertolo R (2006) Hidrogeología del Brasil: una breve crónica de las potencialidades, problemática y perspectivas. Bol Geol Minero 117:25-36

IPCC (2014) Climate change 2014: impacts, adaptation, and vulnerability. Contribution of Working Group II to the Fifth Assessment Report of the Intergovernmental Panel on Climate Change. Cambridge University Press, New York
Lang ARG (1967) Osmotic coefficients and water potentials of sodium chloride solutions from 0 to $40^{\circ} \mathrm{C}$. Austral J Chem 20:2017-2023

Maguire JD (1962) Speed of germination-aid in selection and evaluation for seedling emergence and vigor. Crop Sci 2: $176-177$

Marengo JA (2008) Água e mudanças climáticas. Estudos Avançados 22:83-96

Marengo JA (2014) O futuro clima do Brasil. Revista USP 103: 25-32

Matias JR, Oliveira GM, Dantas BF (2014) Colheita e beneficiamento de algumas espécies da Caatinga. Inform Abrates 2422-2426

Meiado MV, Silva FFS, Carvalho DCA, Siqueira Filho JA (2012) Diaspore of the caatinga: a review. Flora of the Caatingas of the São Francisco River: natural history and conservation. 1st edn, Andrea Jakobsson, pp 306-365

Merino-Martín L, Courtauld C, Commander L, Turner S, Lewandrowski W, Stevens J (2017) Interactions between seed functional traits and burial depth regulate germination and seedling emergence under water stress in species from semi-arid environments. J Arid Environm 147:25-33

Moreno C, Seal CE, Papenbrock J (2018) Seed priming improves germination in saline conditions for Chenopodium quinoa and Amaranthus caudatus. J Agron Crop Sci 204:40-48

Moura MSB, Galvincio JD, Brito LT L, Souza LSB, Sá IIS, Silva TGF (2007) Clima e água de chuva no Semi-Árido. In Brito LT L, Moura MSB, Gama GFB (eds) Potencialidades da água de chuva no Semi-Árido brasileiro. Petrolina, Embrapa Semi-Árido, pp 37-59

Nascimento JPB, Meiado MV, Siqueira-Filho JA (2018) Seed germination of three endangered subspecies of Discocactus Pfeiff. (Cactaceae) in response to environmental factors. $J$ Seed Sci 40:253-262

Nasr SMH, Parsakhoo A, Naghavi H, Koohi SKS (2012) Effect of salt stress on germination and seedling growth of Prosopis juliflora (Sw.). New Forests 43:45-55

Oliveira GMD, Silva FFSD, Araujo MDN, Costa DCCD, Gomes SEV, Matias JR, Angelotti F, Pelacani-Cruz CR, Seal CE, Dantas BF (2019) Environmental stress, future climate, and germination of Myracrodruon urundeuva seeds. J Seed Sci 41:32-43

Ooi MK, Auld TD, Denham AJ (2012) Projected soil temperature increase and seed dormancy response along an altitudinal gradient: implications for seed bank persistence under climate change. $P l \&$ Soil 353:289-303

Paim LP, Avrella ED,Fior CS (2016) Germinação de sementes de Anadenanthera colubrina (Vellozo) Brenan em diferentes temperaturas. Rev J Pós-Graduação e Pesq Congrega Urcamp 573-582

Paterno GB, Siqueira Filho JA, Ganade G (2016) Species-specific facilitation, ontogenetic shifts and consequences for plant community succession. $J$ Veg Sci 27:606-615

PBMC (2014) Base cientifica das mudanças climáticas. Contribuição do Grupo de Trabalho 1 do Painel Brasileiro de Mudanças Climáticas ao Primeiro Relatório da Avaliação Nacional sobre Mudanças Climáticas. COPPE. Universidade Federal do Rio de Janeiro, Rio de Janeiro, RJ, Brasil

Pedrotti A, Chagas RM, Ramos VC, Nascimento Prata AP, Lucas AAT, dos Santos PB (2015) Causes and consequences of the process of soil salinization. REGET 19:1308-1324 
Pereira HM, Ferrier S, Walters M, Geller GN, Jongman RHG, Scholes RJ, Bruford MW, Brummitt N, Butchart SHM, Cardoso AC et al. (2013) Essential biodiversity variables. Science 339:277-278

Queiroz LP (2009) Legumes of the Caatinga. Royal Botanic Garden Edinburgh

Ranal MA, Santana DGD (2006) How and why to measure the germination process? Brazil J Bot 29:1-11

Ribeiro LC, Borghetti F (2014) Comparative effects of desiccation, heat shock and high temperatures on seed germination of savanna and forest tree species. Austral Ecol 39:267-78

Sala OE, Lauenroth WK (1982) Small rainfall events: an ecological role in semiarid regions. Oecologia 53:301-304

Sales NM, Pérez-García F, Silveira FAO Consistent variation in seed germination across an environmental gradient in a Neotropical savana $S$ African J Bot 87:129-133

Santos TEM, Montenegro AAA, Silva DD (2011) Umidade do solo no semiárido pernambucano usando-se reflectometria no domínio do tempo (TDR). Rev Brasil Engen Agríc Ambient 15:670-679

Schimel JP, Gulledge JM, Clein-Curley JS, Lindstrom JE, Braddock JF (1999) Moisture effects on microbial activity and community structure in decomposing birch litter in the Alaskan taiga. Soil Biol Biochem 31:831-838
Silva FAS, Azevedo CAV (2016) The Assistat Software Version 7.7 and its use in the analysis of experimental data. African $J$ Agric Res 11:3733-3740

Siqueira Filho JA (2012) Flora of the Caatingas of the São Francisco River: natural history and conservation. 1st edn, Andrea Jakobsson

Sovu PS, Tigabu M, Odén PC (2010) Restoration of former grazing lands in the highlands of Laos using direct seeding of four native tree species. Mountain Res Developm 30:232 243

SUDENE (1980) Plano de aproveitamento integrado dos recursos hídricos do Nordeste do Brasil - fase I: recursos hídricos I águas subterrâneas. 7th edn, Departamento de Recursos Naturais.

Vásquez-Yanes C, Orozco-Segovia A (1993) Patterns of seed longevity and germination in the tropical rainforest. Ann Rev Ecol Syst 24:69-87

Vieira DLM, Scariot A (2006) Principles of natural regeneration of tropical dry forest for restoration. Restorat Ecol 14:11-20

Wiersema JH, León B (2016) World economic plants: a standard reference. Boca Raton

Publisher's note Springer Nature remains neutral with regard to jurisdictional claims in published maps and institutional affiliations. 